\title{
A surge of MDR and XDR tuberculosis in France among patients born in the Former Soviet Union
}

C Bernard (christine.bernard@psl.aphp.fr) ${ }^{1,2,3}$, F Brossier ${ }^{1,2,3}$, W Sougakoff ${ }^{1,2,3}$, N Veziris ${ }^{1,2,3}$, M Frechet-Jachym ${ }^{4}$, N Metivier ${ }^{4}$, A Renvoisé ${ }^{1,2,3}$, J Robert ${ }^{1,2,3}$, V Jarlier ${ }^{1,2,3}$, on behalf of the MDR-TB Management group of the NRC ${ }^{5}$

1. Centre National de Référence des Mycobactéries et de la Résistance des Mycobactéries aux Antituberculeux (National reference centre for mycobacteria and resistance of micobacteria to antituberculous drugs), Paris, France

2. UPMC Paris 06 (Pierre and Marie Curie University Paris), ER 5, EA 1541, Laboratoty of Bacteriology and Hygiene, Paris, France

3. Laboratory of Bacteriology and Hygiene, Hôpital Pitié-Salpêtrière, AP-HP, Paris, France

4. Medical Centre of Bligny, Briis sous Forges, France

5. The members of the team are listed at the end of the article

Citation style for this article:

Bernard C, Brossier F, Sougakoff W, Veziris N, Frechet-Jachym M, Metivier N, Renvoisé A, Robert J, Jarlier V, on behalf of the MDR-TB Management group of the NRC. A surge of MDR and XDR tuberculosis in France among patients born in the Former Soviet Union. Euro Surveill. 2013;18(33):pii=20555. Available online: http://www. eurosurveillance.org/ViewArticle.aspx?Articleld=20555

Article submitted on 12 August 2013 / published on 15 August 2013

A marked increase in the number of multidrug-resistant (MDR) tuberculosis (TB) cases entirely related to patients born in the Former Soviet Union was observed in France in the last two years. Very few cases were clustered, suggesting it is a consequence of recent immigration of patients already infected in their country of origin. This major increase challenges the existing structures for management of MDR and extensively drug-resistant TB (XDR-TB).

We report herein a drastic surge in the number of multidrug-resistant tuberculosis (MDR-TB) cases diagnosed in France in the last two years. MDR-TB, defined as TB with Mycobacterium tuberculosis strains resistant to isoniazid (INH) and rifampicin (RMP), is a threat to public health in some parts of the world, notably in Eastern Europe and Central Asia [1-4]. In these regions, and particularly in Former Soviet Union (FSU) countries, nearly one third of new cases and two thirds of previously treated cases are MDR-TB cases $[2,5]$. In France, which is a low TB incidence country [6], MDR-TB represented $0.7 \%$ of new cases and $6.9 \%$ of previously treated cases up to 2004 [7].

Surveillance of resistant tuberculosis

All MDR-TB strains sent to the French National Reference Center for Mycobacteria (NRC-MyRMA) between 2006 and 2012 for MDR confirmation and second-line drug susceptibility testing against ofloxacin (OFX), amikacin (AMK), kanamycin (KAN), and capreomycin (CAP) were included. Susceptibility tests were performed on Lowenstein-Jensen medium following the proportion method [8], by using the critical proportion of $1 \%$ and the following concentrations: RMP $40 \mathrm{mg} / \mathrm{L}$, INH 0.2 and $1 \mathrm{mg} / \mathrm{L}$, OFX $2 \mathrm{mg} / \mathrm{L}$, AMK and CAP $40 \mathrm{mg} / \mathrm{L}$, KAN $30 \mathrm{mg} / \mathrm{L}$. Detection of mutations involved in the resistance to the above antibiotics was performed by using the line probe assays MTBDRplus and MTBDRsl (HAIN Lifescience) and by gyrA and gyrB sequencing.
Extensively drug-resistant TB (XDR-TB) was defined as MDR-TB with additional resistance to any of the fluoroquinolones and to at least one of the three injectable drugs, KAN, AMK or CAP, and pre-XDR-TB was defined as MDR-TB with additional resistance to either fluoroquinolones or one of the three injectable drugs. Genotyping was performed using the 24-loci mycobacterial interspersed repetitive-unit variable-number tandem repeat (MIRU-VNTR) method. A cluster was defined as two or more patients whose strains had identical genotype pattern.

\section{Results}

The NRC-MyRMA received 409 MDR strains from distinct patients between 2006 and 2012. The annual number of MDR-TB strains remained stable around 50 between 2006 and 2010, but increased to 69 in 2011 and 92 in 2012. The surge was related to an increase in patients born in the FSU, from an annual average of nine in 2006 to 2010 to 21 in 2011, and 47 in 2012 (Figure 1).

\section{FIGURE 1}

Distribution by country of birth of patients with multidrug-resistant tuberculosis identified in France, 2006-12 $(n=409)$

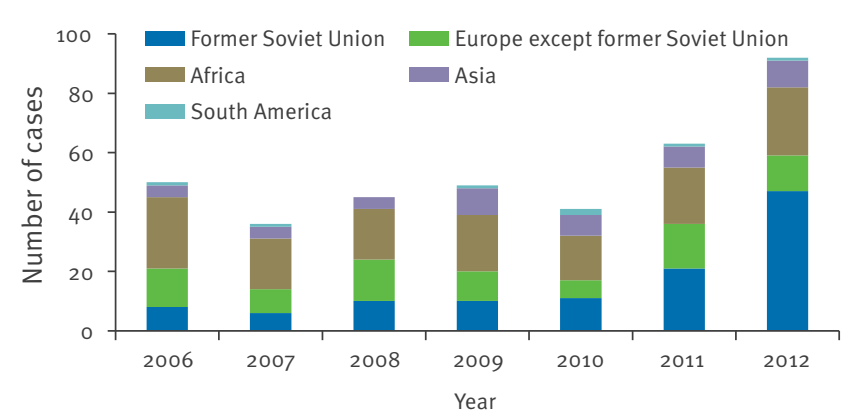




\section{FIGURE 2}

Distribution by country of birth of patients with multidrug-resistant tuberculosis born in the former Soviet Union, France, 2006-12 ( $\mathrm{n}=113)$

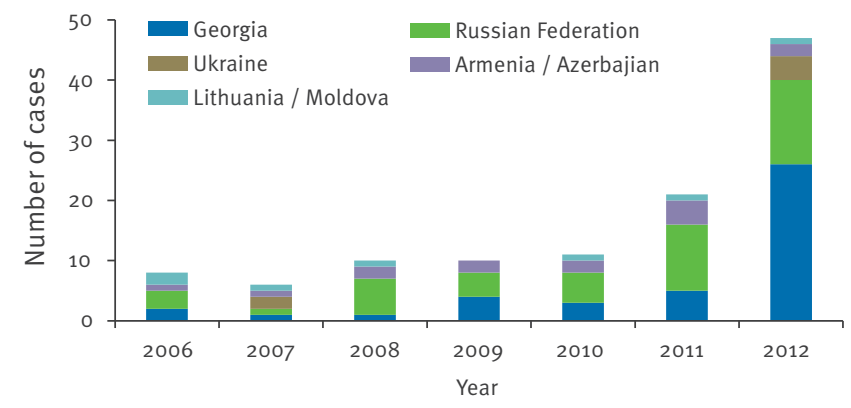

The annual number of patients born in Georgia rose from ca. two cases in 2006 to 2010 to five in 2011 and 26 in 2012 (Figure 2); for those born in the Russian Federation from ca. four in 2006 to 14 in 2012; and for those born in Ukraine from two cases in 2007 to four cases in 2012. The number of patients who originated from other parts of the world remained stable, except for those born in Eastern Europe outside the FSU, who doubled from an annual average of four in 2006 to 2008 to eight in 2009 to 2012.

Furthermore, the annual number of XDR-TB cases increased from two in 2006 to 2008 (5\% of MDR-TB) to four in 2009 (7\% of MDR-TB), six in 2010 (13\% of MDR-TB), seven in 2011 (10\% of MDR-TB) and suddenly 17 in 2012 (18\% of MDR-TB) (Figure 3).

Almost three quarters of the $40 \mathrm{XDR}$-TB strains $(n=31)$ were isolated from patients born in FSU, the remaining being born in other European countries $(n=4)$ and in Africa $(n=5)$. All 17 XDR strains identified in 2012 were from patients born in FSU, including 14 born in Georgia. Among all 113 MDR strains identified in FSUborn patients during the seven-year period, 31 (27\%) were XDR, compared to nine of 296 (3\%; p $<0.001$ ) among strains isolated from patients born in other countries. Among the 92 MDR strains in 2012, the proportion of XDR and pre-XDR strains was higher for patients born in Georgia (89\%) than for other FSU countries ( $52 \%$; p 0.01$)$, and for non-FSU countries (9\%; p<o.001) (Table).

Among the 47 FSU-born patients harbouring MDR strains isolated in 2012 with a mean age of 33 years, 36 were male ( 28 for other countries; $p=0.13$ ), 31 smearpositive ( 21 for other countries; $p=0.05$ ), and 28 previously treated ( 15 for others countries; $p=0.01$ ) (Table). The date of arrival in France was known for 29 of the 47 FSU-born MDR-TB patients identified in 2012: 27 arrived within one year before hospitalisation, including 10 that arrived within one month. The two remaining patients were in France for two and 10 years, respectively.
The MIRU-VNTR patterns of the 47 strains isolated in 2012 from FSU-born patients revealed that $32(68 \%)$ belonged to the Beijing lineage, 10 (21\%) to the LAM lineage, one to the Haarlem and one to the Ural lineages. Three isolates had MIRU-VNTR patterns referred as non-typable. Three clusters of five, nine and 10 strains were identified among the 32 Beijing strains, and three clusters of two, two and three strains among the 10 LAM strains. The combination of phenotypic and genotypic antibiotic patterns with MIRU-VNTR patterns decreased the clustering to only one pair in the Beijing lineage and one pair in the LAM lineage, each related to individuals within one household. All other strains had distinct genotypic and phenotypic susceptibility profiles ruling out transmission. Of note, only six (two patients born in China, one in Mongolia, one in France and two in Africa) of the MDR strains from non-FSU patients belonged to the Beijing lineage.

\section{Discussion}

In France, the sudden increase in the number of MDR-TB strains isolated since 2011 was almost entirely related to the surge of MDR strains from FSU-born patients, who accounted for more than $50 \%$ of MDR-TB cases in 2012. Specifically, the increase was related to patients born in Ukraine, the Russian Federation and above all in Georgia.

In these three countries, TB incidence was estimated to be between 90 and 125 per 100,000 population in 2011 and the percentages of MDR-TB cases are estimated to be $10-20 \%$ in new TB cases and ca. $45 \%$ in retreatment cases [9-12]. Because Ukraine and the Russian Federation are countries with high numbers of inhabitants ( 45 and 143 million, respectively) in contrast to Georgia (4.3 million inhabitants), it is to be expected that more MDR-TB patients are observed originating from Ukraine and the Russian Federation than from Georgia. This is in contrast with what we observed in 2012, when Georgian patients accounted for more than half of MDR-TB cases from the FSU. This suggests that Georgian patients with MDR-TB may be more likely to emigrate to France and that MDR-TB rates in emigrates

\section{FIGURE 3}

Distribution by country of birth of patients with extensively drug-resistant tuberculosis, France, 2006-12 $(n=40)$

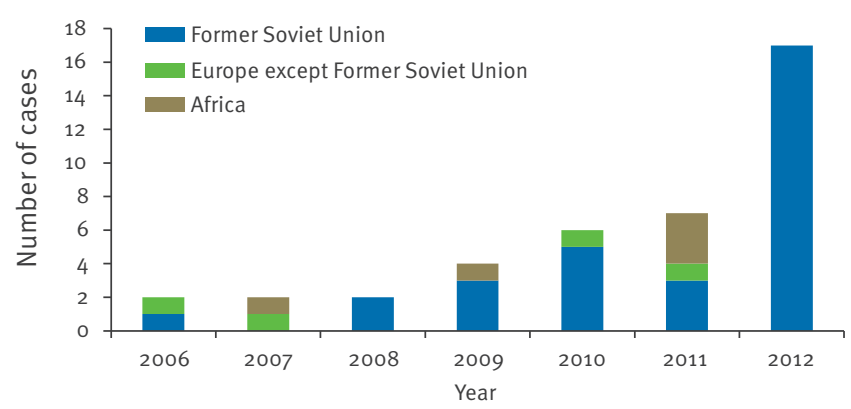


Characteristics of patients with multidrug-resistant tuberculosis identified in 2012, by region of birth, France ( $\mathrm{n}=92$ )

\begin{tabular}{|c|c|c|c|c|c|}
\hline Characteristic & $\begin{array}{c}\text { Georgia } \\
(n=26)\end{array}$ & $\begin{array}{c}\text { FSU except Georgia } \\
(n=21)\end{array}$ & $\begin{array}{c}\text { Total FSU } \\
(\mathrm{n}=47)\end{array}$ & $\begin{array}{l}\text { Other countries } \\
\quad(n=45)\end{array}$ & $\mathrm{p}$ value \\
\hline Mean age (years) & 36 & 30 & 33 & 28 & 0.01 \\
\hline Male n (\%) & $23(89)$ & $14(65)$ & $36(77)$ & $28(62)$ & 0.13 \\
\hline Smear positive $\mathrm{n}(\%)$ & $19(73)$ & $12(62)$ & $31(66)$ & $21(46)$ & 0.05 \\
\hline Previous treatment $\mathrm{n}(\%)$ & $18(67)$ & $10(50)$ & $28(60)$ & $15(33)$ & 0.01 \\
\hline XDR-TB n (\%) & $14(54)$ & $3(14)$ & $17(36)$ & 0 & $<0.01$ \\
\hline Pre-XDR-TB n (\%) & $9(35)$ & $8(38)$ & $17(36)$ & $4(9)$ & $<0.01$ \\
\hline Pre-XDR and XDR-TB n (\%) & $23(89)$ & $11(52)$ & $34(72)$ & $4(9)$ & $<0.01$ \\
\hline Beijing lineage $n(\%)$ & $16(62)$ & $16(76)$ & $32(68)$ & $6(13)$ & $<0.01$ \\
\hline
\end{tabular}

FSU: Former Soviet Union; XDR-TB: extensively drug-resistant tuberculosis.

a Comparison between total FSU and other countries.

cannot be deduced from rates observed in their countries of origin [13].

Previous TB treatment history is known to be a risk factor for resistance [14-16], and this is confirmed in France where two thirds of the FSU-born MDR-TB patients have been previously treated. In addition, more than one third of the FSU-born MDR-TB patients from 2012 had in fact XDR-TB, and all of the XDR-TB patients were FSU-born. Consequently, the important surge in MDR-TB observed recently in France is compounded by a problematic management of antibiotic treatment regimens before the availability of comprehensive susceptibility tests results, reinforcing the importance of universal use of genotypic susceptibility tests in this population. While it is possible that an increase in immigration from the FSU overall could in part explain the observed increase in cases, it is worth mentioning that nine in 10 FSU-born MDR-TB patients are recent immigrants and that one in three arrived only a few days before hospitalisation. Therefore, the possibility needs to be considered that immigration to France may be driven by health reasons and clinicians should be aware of it when such patients arrive in the healthcare system.

In the present study, the genotyping analysis revealed four lineages (Beijing, LAM, Haarlem and Ural) already reported in the FSU [17-19], although the Beijing family was more frequent (68\%) in our study. Of interest, the combination of MIRU-VNTR and antibiotic resistance genotypes and phenotypes suggested that almost all strains defined as clustered by MIRU-VNTR were in fact distinct. Thus, the recent increase in France in the number of FSU-born MDR-TB patients is more likely to be a result of recent immigration of patients infected in their country of birth where multiple MDR strains are circulating, than from cross-transmission in France among a closed group.
In conclusion, this increase challenges the existing structures for management of MDR and XDR-TB especially in a low-endemic country for TB.

The members of the MDR-TB Management group of the NRC were:

Claire Andrejak, , Amiens; Emmanuelle Cambau,Paris; Katarina Chadelat, Paris; Bertrand Dautzenberg, Paris; Benoit Henry, Paris; Damien Le Dû, Briis sous Forges, Laurent Raskine, Paris; Benedicte Rivoire, Paris; Guillaume Thouvenin, Paris.

\section{Conflict of interest}

None declared

Authors' contributions

Christine Bernard, Florence Brossier, Nicolas Veziris, Vincent Jarlier, Wladimir Sougakoff, Jerome Robert, Aurélie Renvoisé: collected, analysed and interpreted data. Christine Bernard, Vincent Jarlier, Jerôme Robert: wrote the manuscript. All authors provided contribution with comments and reviewed the manuscript.

\section{* Erratum:}

The name of A Renvoisé was erroneously left out of the list of authors at the time of publication of this article. This mistake was corrected on 16 August 2013 and we apologise to the authors. 


\section{References}

1. World Health Organization (WHO). Global tuberculosis report 2012. Geneva: WHO; 2012. Available from: http://www.who. int/tb/publications/global_report/en/index.html

2. Zignol M, Van Gemert W, Falzon D, Sismanidis C, Glaziou P, Floyd K, et al. Surveillance of anti-tuberculosis drug resistance in the world: an updated analysis, 2007-2010. Bull World Health Organ. 2012;90(2):111-9. http://dx.doi.org/10.2471/ BLT.11.092585 PMid:22423162 PMCid:PMC3302554

3. Dewan P, Sosnovskaja A, Thomsen V, Cicenaite J, Laserson $\mathrm{K}$, Johansen I, et al. High prevalence of drug-resistant tuberculosis, Republic of Lithuania, 2002. Int J Tuberc Lung Dis. 2005;9(2):170-4. PMid:15732736

4. Raviglione MC, Rieder HL, Styblo K, Khomenko AG, Esteves $\mathrm{K}$, Kochi A. Tuberculosis trends in eastern Europe and the former USSR. Tuber Lung Dis. 1994;75(6):400-16. http://dx.doi. org/10.1016/0962-8479(94)90113-9

5. Skrahina A, Hurevich $H$, Zalutskaya A, Sahalchyk E, Astrauko A, Van Gemert W, et al. Alarming levels of drug-resistant tuberculosis in Belarus: results of a survey in Minsk. Eur Respir J. 2012;39(6):1425-31. http:// dx.doi.org/10.1183/09031936.00145411 PMid:22005924 PMCid:PMC3393766

6. Antoine D. Les cas de tuberculose déclarés en France en 2010. [Tuberculosis cases reported in France in 2010]. BEH. 2012;24-25:285-7. French. Available from : http://www.invs. sante.fr/content/download/38173/181054/version/4/file/ beh_24_25_2012.pdf

7. Khuê PM, Truffot-Pernot C, Texier-Maugein J, Jarlier $V$, Robert J. A 10-year prospective surveillance of Mycobacterium tuberculosis drug resistance in France 1995-2004. Eur Respir J. 2007;30(5):937-44. http://dx.doi. org/10.1183/09031936.00037207 PMid:17567675

8. Canetti G, Rist N, Grosset J. [Measurement of sensitivity of the tuberculous bacillus to antibacillary drugs by the method of proportions. Methodology, resistance criteria, results and interpretation]. Rev Tuberc Pneumol (Paris). 1963;27:217-72. French.

9. World Health Organization (WHO). Tuberculosis country profiles [Internet]. Geneva: WHO. [Accessed: Mar 2013]. Available from: http://www.who.int/tb/data

10. Lomtadze N, Aspindzelashvili R, Janjgava M, Mirtskhulava V, Wright A, Blumberg HM, et al. Prevalence and risk factors for multidrug-resistant tuberculosis in the Republic of Georgia: a population-based study. Int J Tuberc Lung Dis. 2009;13(1):6873. PMid:19105881 PMCid:PMC2645031

11. Mdivani N, Zangaladze E, Volkova N, Kourbatova E, Jibuti T, Shubladze N, et al. High prevalence of multidrug-resistant tuberculosis in Georgia. Int J Infect Dis. 2008;12(6):635-44. http://dx.doi.org/10.1016/j.ijid.2008.03.012 PMid:18514008 PMCid:PMC2645041

12. Vashakidze L, Salakaia A, Shubladze N, Cynamon M, Barbakadze K, Kikvidze M, et al. Prevalence and risk factors for drug resistance among hospitalized tuberculosis patients in Georgia. Int J Tuberc Lung Dis. 2009;13(9):1148-53. PMid:19723406 PMCid:PMC2935085

13. Taylor AB, Kurbatova EV, Cegielski JP. Prevalence of antituberculosis drug resistance in foreign-born tuberculosis cases in the U.S. and in their countries of origin. PLoS ONE. 2012;7(11):e49355. http://dx.doi.org/10.1371/journal. pone.0049355 PMid:23145161 PMCid:PMC3492290

14. Falzon D, Infuso A, Aït-Belghiti F. In the European Union, TB patients from former Soviet countries have a high risk of multidrug resistance. Int J.Tuberc Lung Dis. 2006;10(9):954-8. PMid:16964783

15. Faustini A, Hall AJ, Perucci CA. Risk factors for multidrug resistant tuberculosis in Europe: a systematic review. Thorax. 2006;61(2):158-63. http://dx.doi.org/10.1136/thx.2005.045963 PMid:16254056 PMCid:PMC2104570

16. Clark CM, Li J, Driver CR, Munsiff SS. Risk factors for drugresistant tuberculosis among non-US-born persons in New York City. Int J Tuberc Lung Dis. 2005;9(9):964-9. PMid:16158888

17. Niemann S, Diel R, Khechinashvili G, Gegia M, Mdivani N, Tang Y-W. Mycobacterium tuberculosis Beijing lineage favors the spread of multidrug-resistant tuberculosis in the Republic of Georgia. J Clin Microbiol. 2010;48(10):3544-50. http://dx.doi. org/10.1128/JCM.00715-10 PMid:20702677 PMCid:PMC2953096

18. Mokrousov I, Vyazovaya A, Otten T, Zhuravlev V, Pavlova E, Tarashkevich L, et al. Mycobacterium tuberculosis population in northwestern Russia: an update from Russian-EU Latvian border region. PLoS ONE. 2012;7(7):e41318. http:// dx.doi.org/10.1371/journal.pone.0041318 PMid:22844457 PMCid:PMC3402494

19. Pardini M, Niemann S, Varaine F, lona E, Meacci F, Orrù $\mathrm{G}$, et al. Characteristics of drug- resistant tuberculosis in Abkhazia (Georgia), a high-prevalence area in Eastern Europe. Tuberculosis. 2009;89(4):317-24. http://dx.doi.org/10.1016/j. tube.2009.04.002 PMid:19539531 